\title{
Establishment and characterization of a new cell line, FRTK-1, derived from human malignant rhabdoid tumor of the kidney, with overexpression of epidermal growth factor receptor and cyclooxygenase-2
}

\author{
MICHIYUKI HAKOZAKI ${ }^{1,2}$, HIROSHI HOJO ${ }^{1}$, MICHIKO SATO $^{1}$, YASUHIKO KANEKO ${ }^{3}$, \\ NAOKI WATANABE ${ }^{3,4}$, SHINICHI KIKUCHI ${ }^{2}$ and MASAFUMI ABE ${ }^{1}$

\begin{abstract}
${ }^{1}$ First Department of Pathology and ${ }^{2}$ Department of Orthopaedic Surgery, Fukushima Medical University School of Medicine, 1 Hikarigaoka, Fukushima-shi, Fukushima 960-1295; ${ }^{3}$ Department of Cancer Chemotherapy, Saitama Cancer Center Hospital, 818 Komuro, Ina-machi, Saitama 362-0806; ${ }^{4}$ Department of Pediatrics, Juntendo University Nerima Hospital, 3-1-10 Takanodai, Nerima-ku, Tokyo 177-8521, Japan
\end{abstract}

Received April 13, 2006; Accepted May 16, 2006

\begin{abstract}
A new human malignant rhabdoid tumor (MRT) cell line (designated FRTK-1) was established from MRT of the kidney of an 18-month-old boy. The cell line is maintained for over 24 months with more than 100 passages. FRTK-1 cells in vitro showed 2 different growth patterns, adherent and nonadherent patterns. The FRTK-1 cells showed the same morphological and immunophenotypical characteristics as primary tumor cells of kidney. Cytogenetic and molecular analyses revealed a non-sense mutation in the hSNF5/INI1 gene and loss of expression of hSNF5/INI1 gene product protein. Epidermal growth factor receptor (EGFR) and cyclooxygenase-2 (COX-2) were expressed in the FRTK-1 cells. Until now, there has been no report of MRT cell lines with expression of COX-2. Therefore, FRTK-1 cell line might be useful for investigating biological behavior and developing new molecular targeting antitumor drugs for MRT with expression of EGFR or COX-2.
\end{abstract}

\section{Introduction}

Malignant rhabdoid tumors (MRTs) are very rare and highly aggressive soft tissue sarcomas that occur in childhood, especially in infancy. In 1978, Beckwith and Palmer described renal MRT (MRT of the kidney; MRTK) as a rhabdomyosarcomatoid variant of Wilms' tumor (1). The tumor cells, designated as a 'rhabdoid cell', are histopathologically

Correspondence to: Dr Michiyuki Hakozaki, First Department of Pathology, Fukushima Medical University School of Medicine, 1 Hikarigaoka, Fukushima-shi, Fukushima 960-1295, Japan

E-mail: paco@fmu.ac.jp

Key words: malignant rhabdoid tumor of the kidney, FRTK-1 cell line, hSNF5/INI1 gene, epidermal growth factor receptor, cyclooxygenase- 2 characterized by existence of an eosinophilic intracytoplasmic paranuclear inclusion consisting of whorls of intermediate filaments. MRT and its associated tumors occur most frequently in the kidney and also in other sites including the central nerve system (i.e., atypical teratoid/rhabdoid tumor; AT/RT), soft tissues, liver and chest wall. Abnormalities of the hSNF5/INI1 gene have been reported in MRT and its associated tumors, however, the rhabdoid cells show no evidence of actual rhabdomyoblastic differentiation and the origin still remains unclear.

MRTs frequently show highly aggressive behavior, resistance to multi-agent chemotherapy, and fatal metastasis (2). Therefore, in order to improve aggressive course or prognosis, molecular genetic and biological characterizations are required.

To our knowledge, 16 permanent MRT cell lines including 8 MRTK (3-8), 7 extrarenal MRT (6,9-12) and 1 AT/RT (13) have been previously established and characterized. However, these cell lines have not been investigated enough in the aspect of molecular genetic and biological behavior. In the present study, we have established and characterized a new cell line, FRTK-1, derived from MRTK and have investigated overexpression of epidermal growth factor receptor (EGFR) and cyclooxygenase-2 (COX-2) on FRTK-1 to clarify the biological behavior of MRTs.

\section{Materials and methods}

Case report. An 18-month-old Japanese boy presented with macrohematuria. Clinical examination revealed a left upper abdominal mass, and computed tomography showed a primary tumor arising from the left kidney and multiple lung metastases. The left renal tumor was totally resected. Light microscopically, the tumor of the left kidney showed a solid proliferation of small round cells with eosinophilic intracytoplasmic inclusions (Fig. 1). Mitotic figures were frequently seen. On electron microscope, the tumor cells had paranuclear aggregates or whorls of intermediate filaments, which were 


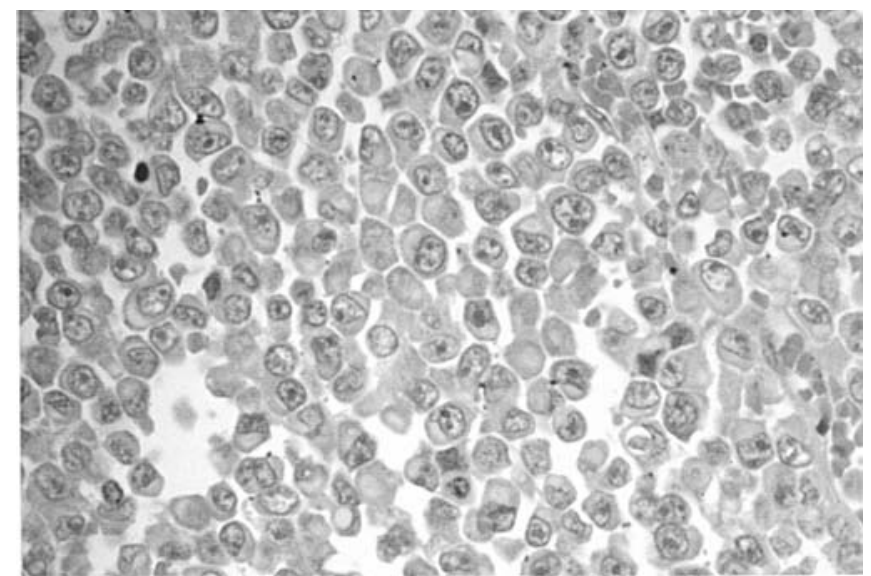

Figure 1. Histology of the primary renal tumor. The tumor cells diffusely proliferate and are small round cells with characteristic eosinophilic intracytoplasmic inclusions.

light microscopically observed as intracytoplasmic inclusions (Fig. 2). Immunohistochemically, the tumor cells were positive for vimentin, neurofilament (NF), epithelial membrane antigen (EMA) and cytokeratins. As a result of pathological findings, the tumor was diagnosed as an MRTK. Two weeks after the operation, followed by adjuvant chemotherapy [etoposide, carboplatin, ifosfamide and pirarubicin]. However, local recurrence, liver metastasis and dissemination of peritoneum, as well as development of multiple lung metastases were found. The patient died of widespread tumor metastasis 3.5 months after the operation at the age of 23 months.

Establishment of cell line. The tumor cells were obtained from the surgical specimen of the left kidney. The cells were cultured at an initial concentration of $1.0 \times 10^{6}$ viable cells $/ \mathrm{ml}$ in RPMI-1640 medium (Sigma R8758, St. Louis, MO, USA) supplemented with $15 \%$ heat-inactivated fetal calf serum (FCS) (JRH Biosciences, Lenexa, KS, USA), 50 units/ml penicillin G, and $50 \mu \mathrm{g} / \mathrm{ml}$ streptomycin. They were inoculated into $25-\mathrm{cm}^{2}$ tissue culture flasks (Iwaki Glass, Tokyo, Japan) and incubated at $37^{\circ} \mathrm{C}$ in a humidified atmosphere with $5 \% \mathrm{CO}_{2}$. The culture medium was changed twice per week. To harvest and transfer the cell line, the cells in the sub-confluent state were treated with 1000 unit/ml Dispase (Sanko-Junyaku, Tokyo, Japan). The cell line was maintained for over 2 years under these culture conditions.

Morphological study. The growth and in vitro morphology of cultured cells were observed with an inverted microscope. Morphologic characteristics were further determined by May-Giemsa staining on cytospin preparations and hematoxylin-eosin staining on paraffin-embedded sections. In addition, a transmission electron microscopic examination was done according to previously established procedures.

Immunohistochemistry. Immunohistochemical analysis was performed on the primary tumor, cultured cells and heterotransplanted tumors using the streptavidin-biotin complex (SABC) method. The antibodies were as follows: vimentin (clone V9, 1:1000 dilution; Dako, Glostrup, Denmark), NF (clone 2F11, 1:100 dilution; Dako), cytokeratins including

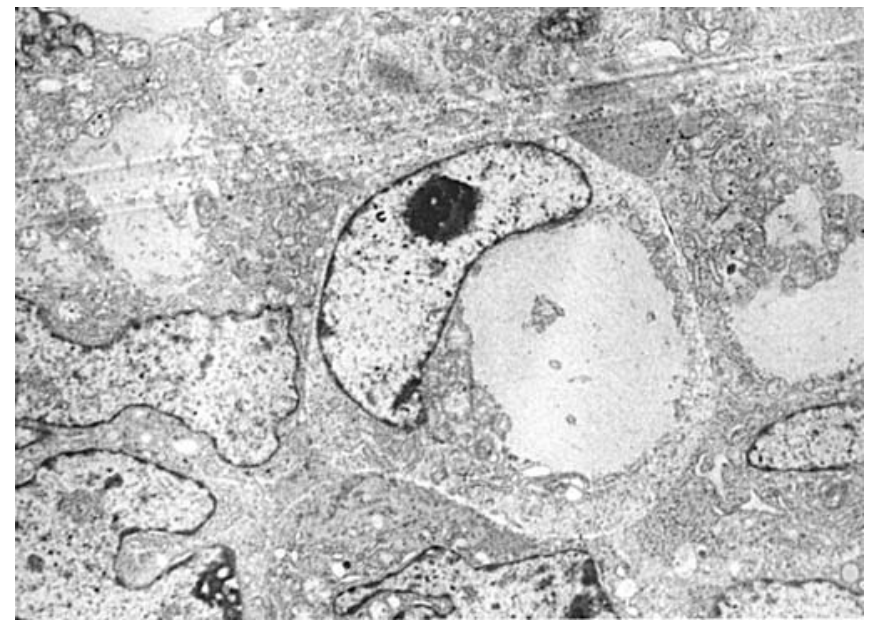

Figure 2. Electron microscopy of primary tumor cells. The tumor cells show inclusion of intermediate filaments in the cytoplasm.

AE1/AE3 (clone AE1 and AE3, 1:200 dilution; Dako), EMA (clone E29, 1:100 dilution; Dako), muscle-specific actin (MSA; clone HHF35, 1:1000 dilution; Dako), desmin (clone D33, 1:20 dilution; Dako), S-100 protein (polyclonal, 1:2000 dilution; Dako), neuron-specific enolase (NSE; polyclonal, 1:3 dilution; Nichirei, Tokyo, Japan), CD99 (MIC-2; clone 12E7, 1:200 dilution, Dako), Ki-67 (MIB-1; clone MIB-1, 1:300 dilution; Dako), p53 gene product protein (p53; clone DO-7, 1:150 dilution; Dako), hSNF5/INI1 (clone 25, 1:200 dilution; BD Biosciences, Franklin Lakes, NJ, USA), EGFR (clone EGFR.25, 1:100 dilution; Novocastra, Newcastle, UK) and COX-2 (clone 4H12, 1:100 dilution; Novocastra).

Cell population doubling time. To determine the doubling time, $2.0 \times 10^{5}$ cells were seeded on $3.5 \mathrm{~cm}$ plastic dishes (BD Falcon 353046, BD Biosciences) with fresh culture medium containing $15 \%$ FCS. The dishes were harvested, and the number of viable cells in each dish was counted by the dye exclusion test $(0.1 \%$ trypan blue in phosphate-buffered saline; PBS) every $12 \mathrm{~h}$ for 5 days.

Heterotransplantation. Severe combined immunodeficiency (SCID) mice (lcr/scid female) and athymic nude mice (BALB/ cA-nu/nu female) at age of 7 weeks were purchased from CLEA Japan (Tokyo, Japan) and kept under sterile conditions. Animal experiments were carried out under the control of our committee in accordance with the guidelines on Animal Experiments in Fukushima Medical University, Japanese Government Animal Protection and Management Law (No. 105) and Japanese Government Notification of Feeding and Safekeeping of Animals (No. 6). The mice were given a single subcutaneous or intraperitoneal injection of $2.5 \times 10^{7}$ cells from the cultured cells in the log phase of growth.

Cytogenetics. Karyotype analysis of the primary tumor cells and established cells was performed commercially by SRL (Tokyo, Japan) using trypsin G-banding technique.

DNA sampling. DNA sample was extracted from the cultured cells using Sepagene (Sanko-Junyaku) according to the manufacturer's protocol. 
Polymerase chain reaction-single strand conformational polymorphism (PCR-SSCP) and direct sequencing analysis for p53 gene. Genomic PCR-SSCP in exons 5-8 of the p53 gene, which are considered to be the mutational hot spot of $\mathrm{p} 53$ gene, was performed on FRTK-1 cells (SRL). Moreover, oligonucleotide sequences in exons 5-9 of the p53 gene were analyzed by direct sequencing. Using Takara Ex Taq HS polymerase (Takara Bio Inc., Shiga, Japan), $0.5 \mu \mathrm{g}$ of DNA were amplified in a total volume of $50 \mu 1$. The sequencing primers were as follows $(14,15)$; exon 5-6 (sense): 5'-TTCC TCTTCCTGCAGTACTC-3'; exon 5-6 (antisense): 5'-AGTT GCAAACCAGACCTCAG-3'; exon 7 (sense): 5'-GTGTTGC CTCCTAGGTTGGC-3'; exon 7 (antisense): 5'-CAAGTGGC TCCTGACCTGGA-3'; exon 8-9 (sense): 5'-CCTATCCTGA GTAGTGGTAA-3'; exon 8-9 (antisense): 5'-CCAAGACT TAGTACCTGAAG-3'. These primers were obtained from Sigma-Aldrich Japan K.K. (Hokkaido, Japan). Polymerase chain reaction (PCR) was done as follows: denaturing at $94^{\circ} \mathrm{C}$ for $10 \mathrm{~min}$ followed by 30 cycles of amplification $\left(94^{\circ} \mathrm{C}\right.$ for $1 \mathrm{~min}, 60^{\circ} \mathrm{C}$ for $1 \mathrm{~min}, 72^{\circ} \mathrm{C}$ for $1 \mathrm{~min}$ ) and 10 -min extension at $72^{\circ} \mathrm{C}$, in a thermal cycler (i-cycler, Bio-Rad Laboratories Inc., CA, USA). One microliter of the PCR product was applied for PCR under the condition consisting of 1 cycle of $95^{\circ} \mathrm{C}$ for $5 \mathrm{~min}$ and 25 cycles of $95^{\circ} \mathrm{C}$ for $30 \mathrm{sec}$ and $60^{\circ} \mathrm{C}$ for $30 \mathrm{sec}$ by the direct sequencing method (Thermo Sequenase core sequencing kit with 7-deaza-dGTP; Amersham, OH, USA). Subsequently, oligonucleotide sequences of exons 5-9 of the p53 gene were analyzed using a sequencer (SQ-5500, Hitachi, Tokyo, Japan) and compared with the germline sequences recorded in the GenBank database.

Direct sequencing analysis for hSNF5/INI1 gene. The mutation analysis was carried out in 9 exons of the hSNF5/INI1 gene. Direct sequencing of 9 exons was performed in FRTK-1 cell line. Using Takara Ex Taq HS polymerase, $0.5 \mu \mathrm{g}$ of DNA were amplified in a total volume of $50 \mu 1$. The sequencing primers were the same as previously described (16), and obtained from Sigma-Aldrich Japan K.K.. PCR was performed as follows: denaturing at $94^{\circ} \mathrm{C}$ for $3 \mathrm{~min}$ followed by 30 cycles of amplification $\left(94^{\circ} \mathrm{C}\right.$ for $1 \mathrm{~min}, 58^{\circ} \mathrm{C}$ for $1 \mathrm{~min}, 72^{\circ} \mathrm{C}$ for $1 \mathrm{~min}$ ) and 5 -min extension at $72^{\circ} \mathrm{C}$, in a thermal cycler. One microliter of the PCR product was applied for PCR under the condition consisting of 1 cycle of $95^{\circ} \mathrm{C}$ for $5 \mathrm{~min}$ and 25 cycles of $95^{\circ} \mathrm{C}$ for $30 \mathrm{sec}$ and $60^{\circ} \mathrm{C}$ for $30 \mathrm{sec}$ by the direct sequence method. Subsequently, oligonucleotide sequences of 9 exons of hSNF5/INI1 gene were analyzed using a sequencer, and compared with the germline sequences recorded in the GenBank database.

Western blot analysis for hSNF5/INII gene product protein, EGFR and COX-2. Cells grown in $25-\mathrm{cm}^{2}$ tissue culture flask were washed twice with ice-cold 0.01 M PBS and scraped in ice-cold 0.01 M PBS, and the cell pellets were lysed in $1 \mathrm{ml}$ of lysis buffer (20 mM Tris-HCl pH 7.4, 1\% NP-40, $1 \mathrm{mM}$ EDTA, $50 \mathrm{mM} \mathrm{NaF}, 50 \mathrm{mM}$ B-glycerophosphate, $0.05 \mathrm{mM}$ $\mathrm{Na}_{3} \mathrm{VO}_{4}, 0.1 \mathrm{mM}$ PMSF, $0.01 \mathrm{mg} / \mathrm{ml}$ aprotinin, $0.01 \mathrm{mg} / \mathrm{ml}$ leupeptin, $0.01 \mathrm{mg} / \mathrm{ml}$ pepstatin) at $4{ }^{\circ} \mathrm{C}$ for $1 \mathrm{~h}$ and clarified by centrifugation (1200 rpm for $15 \mathrm{~min}$ ). Twelve microliter of the supernatant was suspended in $3 \mu 1$ of sample buffer containing 62.5 mM Tris- $\mathrm{HCl}$ pH 6.8, 10\% glycerol, 5\% 2-mercapto- ethanol and $2.3 \%$ SDS. The samples were subjected to SDSPAGE (13\% of polyacrylamide gel for hSNF5/INI1 gene product protein and COX-2, and $7.5 \%$ of polyacrylamide gel for EGFR) under reducing conditions at a constant current of $20 \mathrm{~mA}$. The separated proteins were transferred to PVDF membrane (Millipore, Tokyo, Japan) at a constant current of $300 \mathrm{~mA}$ for $60 \mathrm{~min}$. To block non-specific binding, the membrane was incubated with blocking buffer (Pierce, Rockford, IL, USA) according to the manufacturer's protocol. The membrane was washed with washing buffer, and incubated with the antibodies of hSNF5/INI1 (clone 25, 1:250 dilution; BD), EGFR (1005; sc-03, 1:1000 dilution; Santa Cruz, CA, USA) and COX-2 (H-62; sc-7951, 1:200 dilution; Santa Cruz). After washing, the membrane was incubated with $1 \mu \mathrm{g} / \mathrm{ml}$ anti-mouse or anti-rabbit immunoglobulin (Bio-Rad Laboratories Inc.). The proteins were visualized using the ECL Western blotting detection reagents and analysis system (Amersham). HBL-3, which was the human acute lymphoblastic leukemia cell line established in our laboratory (17), was served as a positive control for hSNF5/INI1.

$R N A$ preparation and reverse transcription- $P C R$ (RT-PCR) analysis for EGFR and Cox-2 mRNA expression. Total-RNA from FRTK-1 cell line was isolated using Isogen reagent (Wako Pure Chemical Industries, Osaka, Japan). After priming of $5 \mu \mathrm{g}$ of total-RNA with $1 \mu 1$ of 1000 pmol random hexadeoxynucleotide primers (Takara Bio Inc.) and $1 \mu 1$ of $10 \mathrm{mM}$ dNTP mixture (Takara Bio Inc.), reverse transcription was performed using Super Script III RNase H - Reverse Transcriptase (Invitrogen Corp., CA, USA) according to the manufacturer's protocol. Aliquots of cDNA $(0.5 \mu \mathrm{l})$ were amplified using Takara Ex Taq HS polymerase in a total volume of $50 \mu 1$. For detection of EGFR and Cox-2 mRNA, PCR was performed in a thermal cycler. The housekeeping gene, $\beta$-actin (18), was used as an internal control. PCR for EGFR and $\beta$-actin was performed as follows, denaturing at $94^{\circ} \mathrm{C}$ for $10 \mathrm{~min}$ followed by 35 cycles of amplification $\left(94^{\circ} \mathrm{C}\right.$ for $1 \mathrm{~min}, 56^{\circ} \mathrm{C}$ for $1 \mathrm{~min}$, $72^{\circ} \mathrm{C}$ for $1 \mathrm{~min}$ ) and $10-\mathrm{min}$ extension at $72^{\circ} \mathrm{C}(19)$; and for COX-2, denaturing at $95^{\circ} \mathrm{C}$ for 5 min followed by 40 cycles of amplification $\left(94^{\circ} \mathrm{C}\right.$ for $20 \mathrm{sec}, 59^{\circ} \mathrm{C}$ for $\left.1 \mathrm{~min}\right)$ and 10 -min extension at $59^{\circ} \mathrm{C}(20)$. The sequencing primers were as follows: 5'-CTATGAGATGGAGGAAGACG-3' (sense) and 5'-CAGAGGAGGAGTATGTGTGA-3' (antisense) for EGFR (19), 5'-ATGGAATTACCCAGTTTGTTGAATC-3' (sense) and 5'-TGGAAGCCTGTGATACTTTCTGTACT-3' (antisense) for COX-2 (20), and 5'-GACTATGACTTAGTTGCG TTA-3' (sense) and 5'-GCCTTCATACATCTCAAGTTG-3' for $B$-actin (18). These primers were obtained from SigmaAldrich Japan K.K. PCR reaction products were electrophoresed through $2 \%$ agarose gels containing $0.2 \mathrm{mg} / \mathrm{ml}$ ethidium bromide.

\section{Results}

Immunohistochemical analysis for p53, hSNF5/INI1, EGFR and COX-2 on primary tumor cells. Immunohistochemically, the tumor cells were positive for p53, EGFR and COX-2, but not for hSNF5/INI1 (Table I). In contrast, 2 cases of Wilms' tumor, 2 cases of clear cell sarcoma of the kidney, 2 
Table I. Immunohistochemical reactivity of primary tumor, FRTK-1 cell line (in vitro), and heterotransplanted tumor (in vivo) with various antibodies.

\begin{tabular}{lccc}
\hline Antibodies & $\begin{array}{c}\text { Primary } \\
\text { tumor }\end{array}$ & $\begin{array}{c}\text { FRTK-1 } \\
\text { (in vitro })\end{array}$ & $\begin{array}{c}\text { FRTK-1 } \\
\text { (in vivo })\end{array}$ \\
\hline Vimentin $^{\mathrm{a}}$ & $3+$ & $4+$ & $4+$ \\
NFa $^{\text {in }}$ & $3+$ & $4+$ & $3+$ \\
AE1/AE3 $^{\text {a }}$ & \pm & $1+$ & \pm \\
EMA & $2+$ & $2+$ & $2+$ \\
MSA & - & $2+$ & $3+$ \\
Desmin & - & - & - \\
S-100 protein & - & $2+$ & $2+$ \\
NSE & $1+$ & $2+$ & $2+$ \\
CD99 (MIC-2) & - & - & $1+$ \\
Ki-67 (MIB-1) & $2+$ & $3+$ & $3+$ \\
p53 & $1+$ & $2+$ & $2+$ \\
hSNF5/INI1 & - & - & - \\
EGFR & $3+$ & $2+$ & $3+$ \\
COX-2 & $4+$ & $4+$ & $4+$ \\
\end{tabular}

-, negative; \pm , rare cell positive $(<1 \%$ positive cells); $1+,<10 \%$ positive cells; $2+, 10-50 \%$ positive cells; $3+, 50-90 \%$ positive cells; $4+,>90 \%$ positive cells; ${ }^{a}$ Positive for intracytoplasmic inclusion.

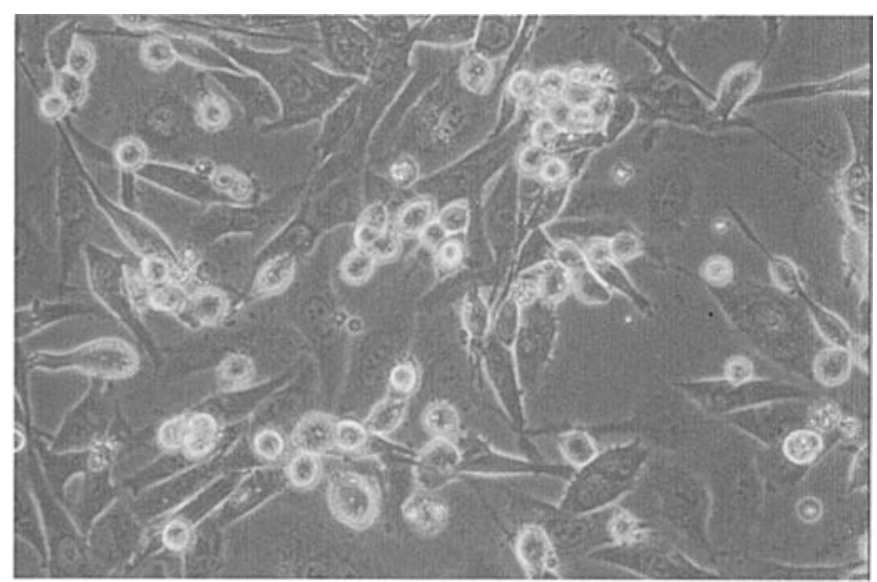

Figure 3. Inverted microscopy of FRTK-1 cells in vitro. The adherent cells are spindle-shaped, stellar or multilateral-shaped without contact inhibition, and non-adherent cells are also observed.

cases of congenital mesoblastic nephroma and 2 cases of malignant lymphoma were all positive for hSNF5/INI1 (data not shown).

Establishment of cell line. A new human malignant rhabdoid tumor cell line, designated FRTK-1, was established from the left kidney of patient with malignant rhabdoid tumor. The doubling time of the cell line was approximately $24 \mathrm{~h}$. The cell line has been stably maintained for over 100 passages. More than half of the cultured cells in vitro were adherent and the others were non-adherent. The adherent cells were spindleshaped, stellar or multilateral-shaped, and loss of contact inhibition was observed. On the other hand, the non-adherent cells showed the round shape (Fig. 3). Both adherent and non-

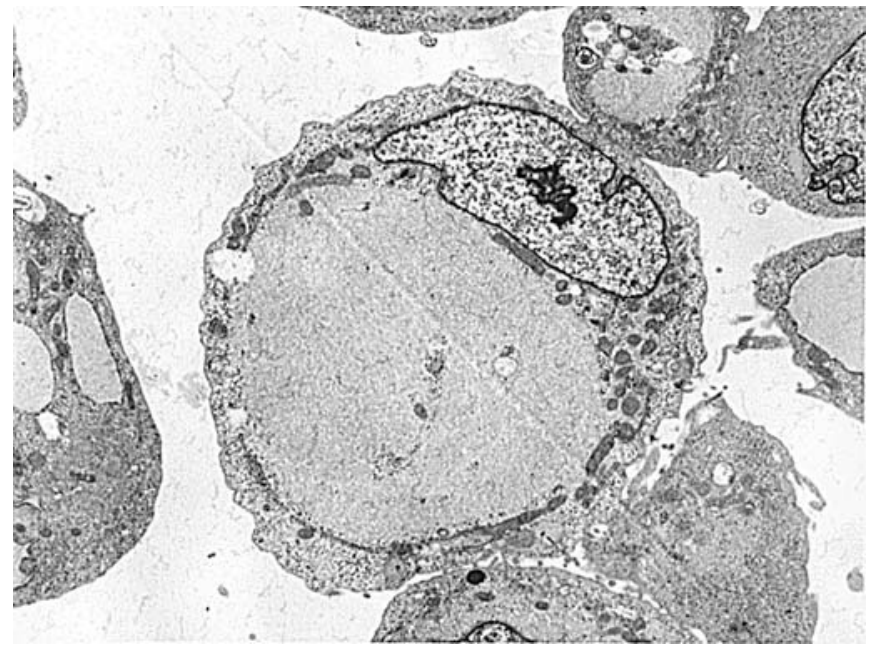

Figure 4. Electron microscopy of FRTK-1 cells. FRTK-1 cells have whorls of intermediate filaments in the cytoplasms.

adherent cultured cells showed rhabdoid features with eosinophilic intracytoplasmic inclusions and no difference in immunohistochemical results between them was found. Electron microscopically, the cultured cells showed the same inclusion of intermediate filaments (Fig. 4) as primary tumor cells. Immunohistochemically, the cultured cells also showed diffusely positive reaction for vimentin, neurofilaments, EMA, S-100 protein, Ki-67, p53 gene product and COX-2 (Fig. 5), and focally positive reaction for AE1/AE3, NSE, CD99 and EGFR, but were negative for MSA, desmin and hSNF5/INI1 (Table I).

Heterotransplantation. FRTK-1 cell line showed successful heterotransplantation into SCID mice and athymic nude mice. In 2 out of 2 SCID mice and 2 of 2 nude mice given a single intraperitoneal injection of FRTK-1 cells, many small nodular tumors developed in the surface of the liver, spleen, mesenterium and peritoneum 14 days after inoculation. The cut surface of the tumors was solid and white. Light microscopically, the tumors showed a solid proliferation of small round cells. There was no metastasis to the brain, lung or kidney and no direct invasions of the liver or spleen in one SCID mouse and 2 nude mice. However, in another SCID mouse, the tumor cells directly invaded the fibrous capsule of liver. Immunohistochemical study showed the same immunoprofile of the primary tumor cells and as the FRTK-1 cells (Table I).

Cytogenetics. Karyotype analysis of G-banded chromosomes for the primary tumor cells showed a reciprocal translocation between chromosomes 10 and 12 [46, XY, t(10;12) (q22; p13)] in 1 out of 21 cells. In FRTK-1 cell line, 3 of 12 cultured cells showed [46, XY, dup(2) (q23;q33)], and 1 cell each showed $[47, \mathrm{XY},+$ mar] and $[47, \mathrm{XY}, \operatorname{add}(7)(\mathrm{q} 32),+$ mar] (data not shown).

PCR-SSCP analysis for p53 gene. In FRTK-1 cell line, no genetic abnormalities were detected in exons 5-8 of p53 gene by PCR-SSCP, and no mutations of oligonucleotide sequences were detected in exons 5-9 of p53 gene by direct sequencing analysis (data not shown). 


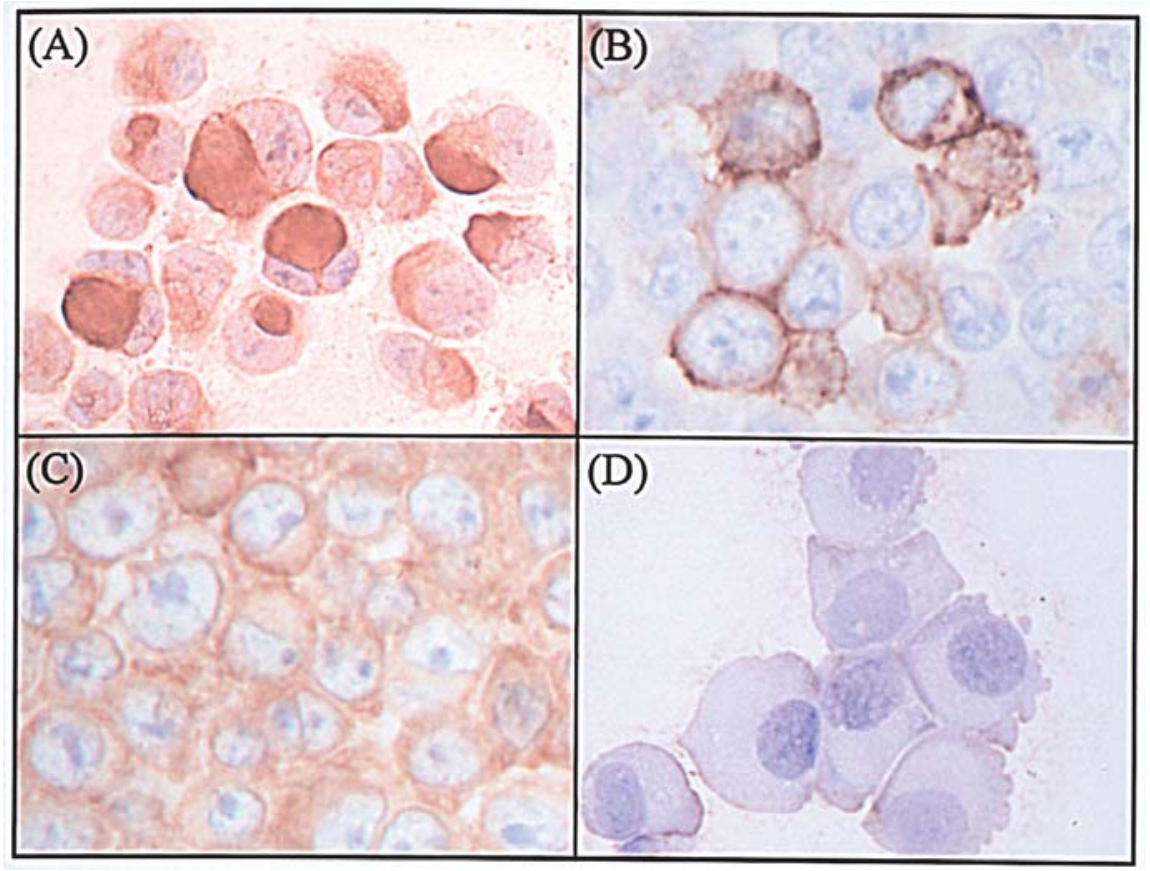

Figure 5. FRTK-1 cells immunohistochemically display positive immunoreactivity for vimentin (A), EGFR (B) and COX-2 (C), but are negative for hSNF5/INI1 gene product protein (D).

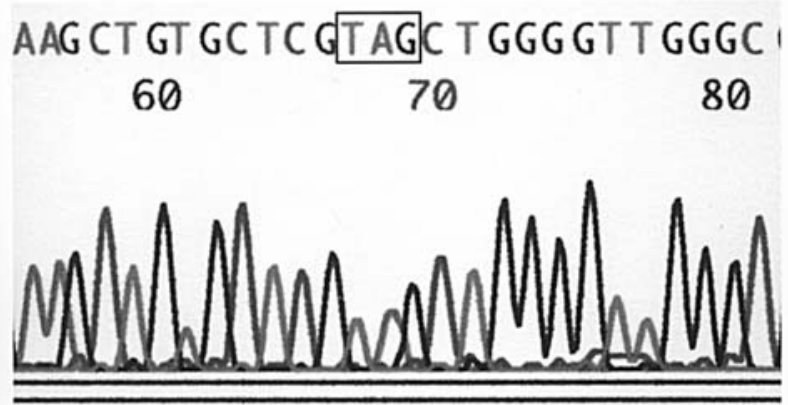

Figure 6. Direct sequencing analysis of hSNF5/INI1 gene shows a non-sense mutation in exon 7 from GAG (glutamine) to TAG (stop codon) at codon 300.

\section{(A) hSNF5/INI1}

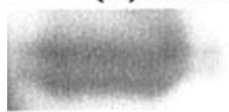

HBL-3

\section{FRTK-1}

(B) EGFR

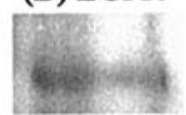

FRTK-1
(C) $\operatorname{COX}-2$

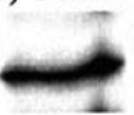

FRTK-1
Figure 7. Western blot analyses of hSNF5/INI1 gene product protein (47 kD), EGFR $(170 \mathrm{kD})$ and COX-2 (70 kD) protein of FRTK-1 cells. No hSNF5/ INI1 gene product protein band is detected in the FRTK-1 cell line, but is detected in the HBL-3 cell line (positive control) (A). The bands of membranous protein EGFR (B) and cytoplasmic protein COX-2 (C) are detected.

Direct sequencing analysis for hSNF5/INII gene. In FRTK-1 cell line, the direct sequencing method detected a point mutation of hSNF5/INI1 gene from GAG to TAG at codon 300, which resulted in conversion from glutamine to stop codon (non-sense mutation) in exon 7 (Fig. 6). No other abnormalities were detected.

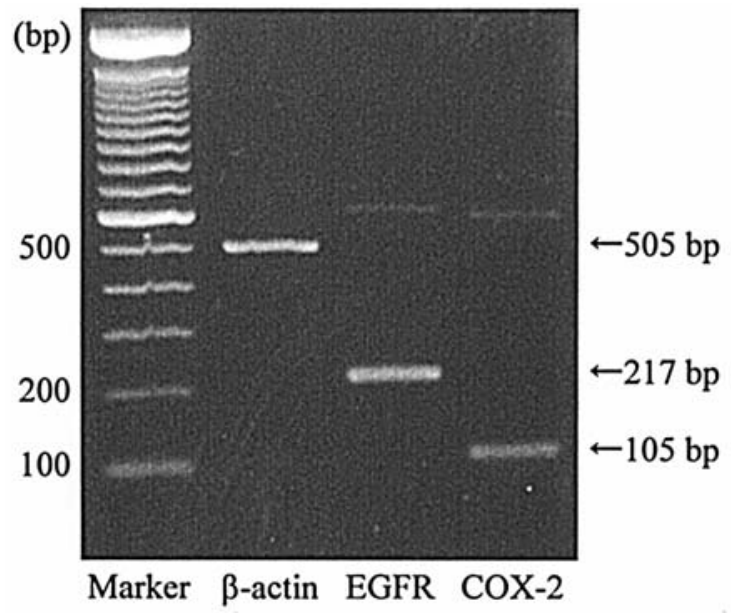

Figure 8. RT-PCR analysis of EGFR and COX-2 mRNA in FRTK-1 cell line. Lane 1, Marker, 100-bp DNA ladder; lane 2, $\beta$-actin (505 bp); lane 3, EGFR (217 bp); lane 4, COX-2 (105 bp). EGFR and COX-2 mRNA are detected.

Western blotting for hSNF5/INI1 gene product protein, EGFR and COX-2. FRTK-1 cells showed no expression of hSNF5/ INI1 gene product protein but expressed EGFR and COX-2 protein (Fig. 7). HBL-3 cells as a positive control expressed hSNF5/INI1 gene product protein.

RT-PCR analysis for EGFR and COX-2 mRNA. Both EGFR and COX-2 mRNA were detected in FRTK-1 by RT-PCR analysis (Fig. 8).

\section{Discussion}

We established a new cell line (FRTK-1) derived from human MRTK. Morphological and immunophenotypic findings 
convincingly showed that FRTK-1 cell line was derived from the primary tumor cells.

Molecular genetic analysis revealed that FRTK-1 cell line had a non-sense mutation in exon 7 in hSNF5/INI1 gene. The aberrations of the hSNF5/INI1 gene (non-sense mutation at codon 300) in FRTK-1 cell line have not been previously reported. The hSNF5/INI1 gene is considered to be a tumor suppressor gene for MRTs (16,21-25) and reported to play a role of suppressing tumor growth in mouse models (26-29). Therefore, the non-sense mutation in exon 7 of FRTK-1 cell line may lead to inactivation of the hSNF5/INI1 gene, thus promoting the tumorigenesis of MRTK.

In 2004, Judkins et al (30) and Hoot et al (31) reported that disappearance of the hSNF5/INI1 protein was specific for AT/RT and MRTs regardless of abnormality in the hSNF5/INI1 gene. Therefore, detection of the hSNF5/INI1 protein by immunohistochemical staining is useful for diagnosis of MRTs including AT/RT. FRTK-1 cells both in vitro and in vivo expressed no hSNF5/INI1 protein, and also primary tumor cells were negative for hSNF5/INI1. Further more, hSNF5/INI1 protein was not detected in FRTK-1 by Western blotting. The data suggest that the non-sense mutation of the hSNF5/INI1 gene leads to disappearance of the hSNF5/INI1 protein and fails to suppress tumorigenesis of MRT.

Kinoshita et al (32) have reported that 5 out of 6 cases of MRTs (3 of 3 renal, and 2 of 3 extrarenal MRTs) showed mutation of the 553 gene, which is one of the most common tumor suppressor genes in various human neoplasms, and suggesting the relevance to its highly aggressive behavior. On the other hand, Rosson et al (6) noted no gene mutation in the p53 gene in 5 MRT cell lines ( 2 renal and 3 extrarenal MRTs). In FRTK-1, no genetic abnormalities were detected in exons 5-9 of the p53 gene. Thus, in FRTK-1, the hSNF5/INI1 gene might mainly behave as a tumor suppressor gene and the p53 gene might have little or no relation with tumorigenesis.

EGFR is a receptor tyrosine kinase and is widely expressed in a variety of epithelial malignancies (33). EGFR activation promotes tumor growth by increasing cell proliferation, motility or angiogenesis, and by blocking apoptosis (34). In MRTs, EGFR expression and cell growth inhibition by anti-EGFR antibody in vitro (17) or by selective EGFR tyrosine kinase inhibitor, Gefitinib (ZD1839, Iressa), in vitro and in vivo (35) have been reported. Therefore, in view of the molecular targeting therapy, EGFR is recognized as a new target for the therapy of MRTs.

COX, also known as prostaglandin $\mathrm{H} 2$ synthase or prostaglandin endoperoxide synthase, is a key enzyme in the conversion of arachidonic acid to prostanoids (36). Two COX genes are cloned; COX-1 is a constitutive enzyme produced constantly in most tissue types, and is probably responsible for the production of prostanoids under physiological conditions, COX-2 is undetectable in most normal tissues, but can be induced in various cell types by pro-inflammatory agents, growth factors and carcinogens (37). Overexpression of COX-2 has been found in various malignancies including carcinomas, lymphomas and some sarcomas. In addition, COX-2 activation promotes tumor growth through production of prostaglandin E2 that could block apoptosis or activate vascular endothelial growth factor and angiogenesis (38). Recent studies have showed antitumor effect of some selective COX-2 inhibitors for sarcomas $(39,40)$ as well as carcinomas. However, COX-2 expression in MRTs has not been reported.

FRTK-1 cells expressed both EGFR and COX-2. Crosstalk between EGFR and COX-2 has been found, and cooperative cell-growth inhibition by the combination treatment with a selective EGFR tyrosine kinase inhibitor and a selective COX-2 inhibitor in malignancies is expected to be efficacious (41). Therefore, FRTK-1 cell line is useful for investigating the antitumor effect of EGFR tyrosine kinase inhibitor combined with COX-2 inhibitors.

In conclusion, we established a new cell line (FRTK-1) derived from MRTK. The FRTK-1 cells showed the same morphological and immunophenotype as those of the primary tumor cells which are characteristic of MRTK, a non-sense mutation of the hSNF5/INI1 gene in exon 7, and expression of EGFR and COX-2 protein. FRTK-1 cell line is useful for investigating biological behavior and developing antitumor therapy of MRT.

\section{Acknowledgements}

The authors thank Mrs. Hiromi Kaneko, Ms. Sachiko Yoshida and Ms. Satomi Hikichi for their skillful technical assistance.

\section{References}

1. Beckwith JB and Palmer NF: Histopathology and prognosis of Wilms tumors: results from the First National Wilms' Tumor Study. Cancer 41: 1937-1948, 1978.

2. Weeks DA, Beckwith JB, Mierau GW and Luckey DW: Rhabdoid tumor of kidney. A report of 111 cases from the National Wilms' Tumor Study Pathology Center. Am J Surg Pathol 13: 439-458, 1989.

3. Gansler T, Gerald W, Anderson G, Gramling TS, Williams CH, Sens D and Garvin AJ: Characterization of a cell line derived from rhabdoid tumor of kidney. Hum Pathol 22: 259-266, 1991

4. Ota S, Crabbe DC, Tran TN, Triche TJ and Shimada H: Malignant rhabdoid tumor. A study with two established cell lines. Cancer 71: 2862-2872, 1993.

5. Hirose M, Yamada T, Abe T, Hirose T, Shimizu E, Yamamoto Y, Kagami S, Takano S, Yamaguchi T and Kuroda Y: Establishment and characterization of two cultured cell lines derived from malignant rhabdoid tumors of the kidney. Int J Cancer 67: 218-223, 1996.

6. Rosson GB, Hazen-Martin DJ, Biegel JA, Willingham MC, Garvin AJ, Oswald BW, Wainwright L, Brownlee NA and Wright CF: Establishment and molecular characterization of five cell lines derived from renal and extrarenal malignant rhabdoid tumors. Mod Pathol 11: 1228-1237, 1998.

7. Sugimoto T, Hosoi H, Horii Y, Ishida H, Mine H, Takahashi K, Abe T, Ohta S and Sawada T: Malignant rhabdoid-tumor cell line showing neural and smooth-muscle-cell phenotypes. Int $\mathbf{J}$ Cancer 82: 678-686, 1999.

8. Kinoshita Y, Tamiya S, Oda Y, Mimori K, Inoue H, Ohta S, Tajiri T, Suita S and Tsuneyoshi M: Establishment and characterization of malignant rhabdoid tumor of the kidney. Oncol Rep 8: 43-48, 2001.

9. Handgretinger R, Kimmig A, Koscielnak E, Schmidt D, Rudolph G, Wolburg H, Paulus W, Schilbach-Stueckle K, Ottenlinger C, Menrad A, Sproll M, Bruchelt G, Dopfer R and Treuner J: Establishment and characterization of a cell line (Wa-2) derived from an extrarenal rhabdoid tumor. Cancer Res 50: 2177-2182, 1990

10. Karnes PS, Tran TN, Cui MY, Bogenmann E, Shimada H and Ying KL: Establishment of a rhabdoid tumor cell line with a specific chromosomal abnormality, 46, XY). Cancer Genet Cytogenet 56: 31-38, 1991. 
11. Misawa A, Hosoi H, Imoto I, Iehara T, Sugimoto T and Inazawa J: Translocation $(1 ; 22)(\mathrm{p} 36 ; \mathrm{q} 11.2)$ with concurrent del(22) (q11.2) resulted in homozygous deletion of SNF5/INI1 in a newly established cell line derived from extrarenal rhabdoid tumor. J Hum Genet 49: 586-589, 2004.

12. Kuroda H, Moritake H, Sawada K, Kuwahara Y, Imoto I, Inazawa J and Sugimoto T: Establishment of a cell line from a malignant rhabdoid tumor of the liver lacking the function of two tumor suppressor genes, hSNF5/INI1 and p16. Cancer Genet Cytogenet 158: 172-179, 2005.

13. Yachnis AT, Neubauer D and Muir D: Characterization of a primary central nervous system atypical teratoid/rhabdoid tumor and derivative cell line: immunophenotype and neoplastic properties. J Neuropathol Exp Neurol 57: 961-971, 1998.

14. Murakami Y, Hayashi K and Sekiya T: Detection of aberrations the $\mathrm{p} 53$ alleles and the gene transcript in human tumor cell lines by single-strand conformation polymorphism analysis. Cancer Res 51: 3356-3361, 1991.

15. Kuze T, Nakamura N, Hashimoto Y, Hojo H, Abe M and Wakasa $\mathrm{H}$ : The relationship between the gene mutation of p53 and the protein expression of p53 and Ki-67 in non-Hodgkin's lymphomas. Pathol Int 46: 130-136, 1996.

16. Versteege I, Sevenet N, Lange J, Rousseau-Merck MF, Ambros P, Handgretinger R, Aurias A and Delattre O: Truncating mutations of hSNF5/INI1 in aggressive paediatric cancer. Nature 394: 203-206, 1998.

17. Abe M, Nakamura N, Fukuhara S, Hayashi T, Kawakami K, Kita K, Kinoshita T, Ohsato T and Wakasa H: A newly established human acute lymphoblastic leukemia cell line with characteristics of the earliest B-cell maturation. Virchows Arch 59: 107-113, 1990.

18. Hashimoto Y, Nakamura N, Kuze T, Abe M and Wakasa H: Intranuclear expression of cyclin D1 protein as a useful prognostic marker for mantle cell lymphoma. Fukushima J Med Sci 43: 87-98, 1997.

19. Narita T, Taga T, Sugita K, Nakazawa S and Ohta S: The autocrine loop of epidermal growth factor receptor-epidermal growth factor/transforming growth factor-alpha in malignant rhabdoid tumor cell lines: heterogeneity of autocrine mechanism in TTC549. Jpn J Cancer Res 92: 269-278, 2001.

20. Yuan A, Yu CJ, Shun CT, Luh KT, Kuo SH, Lee YC and Yang PC: Total cyclooxygenase-2 mRNA levels correlate with vascular endothelial growth factor mRNA levels, tumor angiogenesis and prognosis in non-small cell lung cancer patients. Int J Cancer 115: 545-555, 2005.

21. Kalpana GV, Marmon S, Wang W, Crabtree GR and Goff SP: Binding and stimulation of HIV-1 integrase by a human homolog of yeast transcription factor SNF5. Science 266: 20022006, 1994.

22. Wang W, Cote J, Xue Y, Zhou S, Khavari PA, Biggar SR, Muchardt C, Kalpana GV, Goff SP, Yaniv M, Workman JL and Crabtree GR: Purification and biochemical heterogeneity of the mammalian SWI-SNF complex. EMBO J 15: 5370-5382, 1996.

23. Biegel JA, Zhou JY, Rorke LB, Stenstrom C, Wainwright LM and Fogelgren B: Germ-line and acquired mutations of INI1 in atypical teratoid and rhabdoid tumors. Cancer Res 59: 74-79, 1999.

24. Uno K, Takita J, Yokomori K, Tanaka Y, Ohta S, Shimada H, Gilles FH, Sugita K, Abe S, Sako M, Hashizume K and Hayashi Y: Aberrations of the hSNF5/INI1 gene are restricted to malignant rhabdoid tumors or atypical teratoid/rhabdoid tumors in pediatric solid tumors. Genes Chromosomes Cancer 34: 33-41, 2002.
25. Zhang ZK, Davies KP, Allen J, Zhu L, Pestell RG, Zagzag D and Kalpana GV: Cell cycle arrest and repression of cyclin D1 transcription by INI1/hSNF5. Mol Cell Biol 22: 5975-5988, 2002.

26. Klochendler-Yeivin A, Fiette L, Barra J, Muchardt C, Babinet C and Yaniv M: The murine SNF5/INI1 chromatin remodeling factor is essential for embryonic development and tumor suppression. EMBO Rep 1: 500-506, 2000

27. Roberts CW, Galusha SA, McMenamin ME, Fletcher CD and Orkin SH: Haploinsufficiency of Snf5 (integrase interactor 1) predisposes to malignant rhabdoid tumors in mice. Proc Natl Acad Sci USA 97: 13796-13800, 2000.

28. Guidi CJ, Sands AT, Zambrowicz BP, Turner TK, Demers DA, Webster W, Smith TW, Imbalzano AN and Jones SN: Disruption of Inil leads to peri-implantation lethality and tumorigenesis in mice. Mol Cell Biol 21: 3598-3603, 2001.

29. Roberts CW, Leroux MM, Fleming MD and Orkin SH: Highly penetrant, rapid tumorigenesis through conditional inversion of the tumor suppressor gene Snf5. Cancer Cell 2: 415-425, 2002.

30. Judkins AR, Mauger J, Ht A, Rorke LB and Biegel JA: Immunohistochemical analysis of hSNF5/INI1 in pediatric CNS neoplasms. Am J Surg Pathol 28: 644-650, 2004.

31. Hoot AC, Russo P, Judkins AR, Perlman EJ and Biegel JA Immunohistochemical analysis of hSNF5/INI1 distinguishes renal and extra-renal malignant rhabdoid tumors from other pediatric soft tissue tumors. Am J Surg Pathol 28: 1485-1491, 2004.

32. Kinoshita Y, Shiratsuchi H, Tamiya S, Oshiro Y, Hachitanda Y, Oda Y, Suita S and Tsuneyoshi M: Mutations of the p53 gene in malignant rhabdoid tumors of soft tissue and the kidney: immunohistochemical and DNA direct sequencing analysis. J Cancer Res Clin Oncol 127: 351-358, 2001.

33. Nicholson RI, Gee JM and Harper ME: EGFR and cancer prognosis. Eur J Cancer 37: S9-S15, 2001.

34. Holbro T, Civenni G and Hynes NE: The ErbB receptors and their role in cancer progression. Exp Cell Res 284: 99-110, 2003.

35. Kuwahara Y, Hosoi H, Osone S, Kita M, Iehara T, Kuroda H and Sugimoto T: Antitumor activity of gefitinib in malignant rhabdoid tumor cells in vitro and in vivo. Clin Cancer Res 10: 5940-5948, 2004

36. Vane JR, Bakhle YS and Botting RM: Cyclooxygenases 1 and 2. Annu Rev Pharmacol Toxicol 38: 97-120, 1998.

37. DuBois RN, Abramson SB, Crofford L, Gupta RA, Simon LS, van de Putte LB and Lipsky PE: Cyclooxygenase in biology and disease. FASEB J 12: 1063-1073, 1998.

38. Gately S and Li WW: Multiple roles of COX-2 in tumor angiogenesis: a target for antiangiogenic therapy. Semin Oncol 31: 2-11, 2004.

39. Dickens DS and Cripe TP: Effect of combined cyclooxygenase-2 and matrix metalloproteinase inhibition on human sarcoma xenografts. J Pediatr Hematol Oncol 25: 709-714, 2003.

40. Yamashita H, Osaki M, Honjo S, Yoshida H, Teshima R and Ito H: A selective cyclooxygenase-2 inhibitor, NS-398, inhibits cell growth by cell cycle arrest in a human malignant fibrous histiocytoma cell line. Anticancer Res 23: 4671-4676, 2003.

41. Dannenberg AJ, Lippman SM, Mann JR, Subbaramaiah K and DuBois RN: Cyclooxygenase-2 and epidermal growth factor receptor: pharmacologic targets for chemoprevention. J Clin Oncol 23: 254-266, 2005. 